\title{
FAKTOR-FAKTOR YANG MEMPENGARUHI KEPATUHAN WAJIB PAJAK DALAM MEMBAYAR PAJAK KENDARAAN BERMOTOR (PKB) DI UNIT PELAYANAN PENDAPATAN PROVINSI (UPPP) KABUPATEN SELUMA
}

\author{
R.A. Vivi Yulian Sari \\ Neri Susanti \\ Program Studi Akuntansi \\ Fakultas Ekonomi Universitas Dehasen Bengkulu
}

\begin{abstract}
ABSTRAK
R.A. Vivi Yulian Sari, Neri Susanti; Faktor-Faktor Yang Mempengaruhi Kepatuhan Wajib Pajak dalam Membayar Pajak Kendaraan Bermotor (PKB) di Unit Pelayanan Pendapatan Provinsi (UPPP) Kabupaten Seluma. Penelitian ini bertujuan untuk untukmengetahui faktor-faktor yang mempengaruhi kepatuhan wajib pajak dalam membayar pajakkendaraanbermotor (PKB) di unit Pelayanan Pendapatan Propinsi (UPPP) Kabupaten Seluma.. Jenis penelitian adalah penelitiandeskriktif. Dalam penelitian ini populasi yang digunakan adalah wajib pajak kendaraan bermotor yang terdaftar di Unit Pelayanan Pendapatan Propinsi (UPPP) Kabupaten Seluma, dengansampelyaitu 30 orang wajib pajak kendaraan bermotor roda 2 (dua) yang beralamat di Pasar Tais terdaftar di Unit Pelayanan Pendapatan Propinsi (UPPP) Kabupaten Seluma pada bulan Juli tahun 2013. metode pengumpulan data yang dilakukan yaitu kuesioner. metode analisis data yang digunakan adalah rating scale. Persepsi wajib pajak terhadap sanksi perpajakan menunjukan pengaruh yang signifikan terhadap kepatuhan wajib pajak dalam melaksanakan kewajibannya membayar Pajak Kendaraan Bermotor (PKB), telihat dari posisi nilai persepsi responden terhadap faktor persepsi sanksi perpajakan mempengaruhi kepatuhan wajib pajak dalam membayar pajak kendaraan bermotor di Unit Pelayanan Pendapatan Propinsi (UPPP) Kabupaten Seluma dengan total skor 316 berada pada interval 308-381, kriteria setuju.
\end{abstract}

\begin{abstract}
R.A. Vivi Yulian Sari, Neri Susanti; Factors That Influence Compliance With Taxpayers In Paying Tax On Motor Vehicles In The Province Revenue Service Unit Of Seluma Regency This study aimed to determine the factors that influence taxpayers compliance in paying motor vehicle tax (CLA) in Unit Revenue Services of Province ( UPPP) Seluma District. Type of this study is descriptive study. The population in this study is whousedtaxpayermotor vehicleisregisteredinthe Unit RevenueService of Province (UPPP) SelumaDistrict, witha sample of30taxpayer-wheeled motor vehicletwo (2) located atTaisMarket and registered inUnit RevenueService of Province of(UPPP) Seluma Districtin July2013.The data collected by usingquestionnaire. Data analyzed by using rating scale method. Taxpayer perceptions towards tax penalties showed a significant effect on tax compliance in carrying out its obligations to pay motor vehicle tax (CLA), is seen from the position of the respondent's perception of the value of tax penalties perceptions of factors affecting tax compliance in paying taxes on motor vehicles in Unit Revenue Service of Province( UPPP) Seluma District with the total score of 316 is in the interval 308-381, agreed criteria.
\end{abstract}

\section{Kata kunci: Kepatuhan Wajib Pajak, Pajak Kendaraan Bermotor (PKB)}

\section{PENDAHULUAN}

Tujuan pembangunan nasional adalah menciptakan masyarakat yang adil dan makmur. Dalam rangka tujuan pembangunan nasional, pemerintah melakukan berbagai straregi dalam pembangunan jangka pendek maupun pembanguanan jangka panjang.

Sebelum diadakan tax reform di Indonesia, pembangunan nasional selalu mengandalkan sumber dana yang sebagian besar dari sektor minyak dan gas. Namun setelah tax reform, 
pemerintah menjadikan sektor pajak sebagai sumber utama dalam menompang pembiayaan pembangunan nasional.

Pajak merupakan salah satu sumber penerimaan negara yang penting selain penerimaan lainnya yaitu penerimaan migas maupun penerimaan bukan pajak. Pemerintah berupaya secara terus menerus untuk meningkatkan target penerimaan negara dari sektor pajak.

Penerimaan pajak dipengaruhi oleh pertumbuhan ekonomi suatu negara karena pertumbuhan ekonomi akan meningkatkan pendapatan masyarakat sehingga masyarakat mempunyai kemampuan secara pinansial untuk membayar pajak. Selain itu besarnya pemunggutan pajak, penambahan wajib pajak dan optimalisasi penggalian sumber pajak melalui objek pajak juga berperan dalam meningkatkan penerimaan dari pajak.

Peran pajak sebagai penerimaan dalam negeri menjadi sangat dominan, namun masih belum optimal jika dilihat dari banyaknya wajib pajak yang belum menjadi wajib pajak patuh. Padahal, kebersamaan nasional menuju kemandirian pembangunan menuntut pengabdian dan disiplin yang tinggi. Oleh karena itu, setiap rakyat Indonesia harus sadar bahwa dengan semakin menikmati hasil-hasil pembangunan maka tanggung jawab rakyat terhadap pajak dalam pelaksanaan pembangunan semakin besar. Kesadaran akan tanggung jawab ini menjadi nilai yang fundamental dalam pembangunan dan diharapkan kepatuhan pajak dapat diwujudkan.

Penegakan hukum dalam perpajakan akan mempunyai korelasi yang positif dengan kesuksesan penerimaan pajak. Artinya, pelaksanaan penegakan hukum pajak secara tegas dan konsisten akan mampu menciptakan kepatuhan yang lebih dari wajib pajak, yang bermuara pada peningkatan penerimaan dari sektor pajak. Pemberian sanksi administrasi bagi pelanggar ketentuan perpajakan dimaksud untuk mencegah tingkah laku yang tidak dikendaki sehingga akan tercapai kepatuhan yang lebih dari wajib pajak.

Masalah kepatuhan wajib pajak adalah masalah yang penting di seluruh dunia, baik itu di negara maju maupun di negara berkembang, karena jika wajib pajak tidak patuh maka akan menimbulkan keinginan untuk melakukan tindakan penghindaran,pengelakan dan pelalaian pajak. Sistem pemungutan pajak kendaraan bermotor di Indonesia menganut Official Assessment System, dimana wewenang untuk menentukan besarnya pajak terutang berada pada pemerintah (fiskus). Dengan demikian kepatuhan sukarela dari wajib pajak menjadi tujuan dari sistem ini.

Salah satu upaya dalam meningkatkan kepatuhan wajib pajak adalah memberikan pelayanan yang baik kepada wajib pajak. Peningkatan kualitas dan kuantitas pelayanan diharapkan dapat meningkatan kepuasan kepada wajib pajak sebagai pelanggan sehingga meningkatkan kepatuhan dalam bidang pajak. Paradigma baru yang menempatkan aparat pemerintah sebagai abdi negara dan masyarakat sebagai wajib pajak harus diutamakan agar dapat meningkatkan kinerja pelayanan.

Penegakan hukum dalam pajak kendaraan bermotor diwujudkan melalui pemberian sanksi yaitu berupa pengenaan sanksi administrasi Pajak Kendaraan Bermotor (PKB) kepada wajib pajak yang tidak melakukan pembayaran sesuai jatuh tempo yang terdapat pada Surat Ketetapan Pajak Daerah (SKPD).

Berdasarkan kewenangannya, pajak dapat dibedakan sebagai sebagai pajak pusat dan pajak daerah. Mengenai pajak daerah, peranannya sangat penting sebagai sumber pendapatan daerah dan sebagai penompang pembangunan daerah karena pajak daerah merupakan salah satu sumber Pendapatan Asli Daerah (PAD).

Dengan dikeluarkannya Undang-Undang Nomor 28 Tahun 2009 tentang perubahan atas Undang-Undang Nomor 34 Tahun 2000 tentang Pajak Daerah dan Retribusi Daerah. Pemberian kewenangan dalam pengenaan pajak dan retribusi daerah, diharapkan dapat lebih mendorong pemerintah daerah terus berupaya untuk mengoptimalkan pendapatan asli daearah (PAD), khususnya yang berasal dari pajak daerah yaitu pajak kendaraan bermotor (PKB).

Dalam Undang-Undang Nomor 34 Tahun 2000 dan Peraturan Pemerintah Nomor 28 Tahun 2009 tentang pajak daerah yang menjelaskan perbedaan pajak daerah yang dipungut oleh provinsi dan jenis pajak yang dipungut oleh kabupaten/kota. 
Jenis pajak yang dikelola sesuai Peraturan Pemerintah Propinsi Bengkulu Nomor 2 Tahun 2011, yaitu Pajak Kendaraan Bermotor (PKB), Bea Balik Nama Kendaraan Bermotor (BBN-KB), Pajak Bahan Bakar Kendaraa Bermotor (PBB-KB), Pajak Air Permukaan (PAP) dan pajak rokok.

Unit Pelayanan Pendapatan Propinsi (UPPP) merupakan salah satu sarana pengawasan Pajak Kendaraan Bermotor (PKB) yang memberikan kontribusi dalam penerimaan pajak negara, secara umum UPPP ini bertugas untuk memberikan pelayanan dan pengawasan terhadap pembayaran Pajak Kendaraan Bermotor (PKB).

\section{TINJAUAN LITERATUR \\ Pajak}

Pajak menurut Undang-Undang Nomor 28 Tahun 2007 adalah iuran wajib yang dilalukan oleh orang pribadi atau badan kepada daerah tanpa imbalan langsung yang seimbang yang dapat dipaksakan berdasarkan peraturan perundang-undangan yang berlaku, yang digunakan untuk membiayai penyelenggaraan pemerintah daerah dan pembangunan daerah.

Menurut Aristanti Widyaningsih (2011:2), "pajak adalah iuran rakyat kepada kas negara berdasarkan undang-undang sehingga dapat dipaksakan dengan tiada mendapat balas jasa secara langsung".

Lebih lanjut, Prof. Dr. H. Rochmat Soemitra, SH dalam bukunya Aristanti Widyaningsih (2011:2) mengemukakan "defenisi pajak sebagai peralihan kekayaan dari pihak rakyat kepada kas negara untuk membiayai pengeluaran rutin dan surplusnya digunakan untuk public saving yang merupakan sumber utama untuk membiayai public invesment".

Dari berbagai pendapat tersebut diatas dapat disimpulkan :

1. Pajak dipungut berdasar/dengan kekuatan undang-undang serta aturan pelaksanannya.

2. Dalam pembayaran pajak tidak dapat ditunjukkan adanya kontra prestasi individual oleh pemerintah.

3. Pajak dipungut oleh negara baik pemerintah pusat maupun pemerintah daerah.

4. Pajak diperuntukkan bagi pengeluaran-pengeluaran pemerintah yang bila dari pemasukannya masih terdapat surplus dipergunakan untuk membiayai public investment.

5. Pajak dapat pula membiayai tujuan yang tidak budgeter yaitu mengatur.

Pemberian kewenangan untuk mengadakan pemungutan pajak selain mempertimbangkan kriteria-kriteria perpajakan yang berlaku secara umum, seyogyanya dipertimbangkan optimalisasi ketepatan/kepatuhan dalam membayar pajak. Untuk itu pemerintah daerah dalam melakukan pemungutan pajak harus tetap "menempatkan" sesuai dengan fungsinya. Fungsi yang dimaksud menurut Aristanti Widyaningsing (2011:3) dapat dikelompokan menjadi 5 (lima) yaitu :

1. Fungsi Penerimaan (budgeter) yaitu sebagai sumber dana yang diperuntukan bagi pembiayaan pengeluaran-pengeluaran pemerintah.

2. Fungsi Mengatur (regulator) yaitu seabagi alat untuk mengatur atau melaksanakan kebijakan di bidang sosial dan ekonomi.

3. Fungsi Stabilitas yaitu berhubungan dengan dengan kebijakan untuk menjaga stabilitas harga (melalui dana yang diperoleh dari pajak) sehingga laju inflasi dapat dikendalikan.

4. Fungsi Redistribusi yaitu lebih ditekankan unsur pemerataan dan keadilan dalam masyarakat. Fungsi ini terlihat dari adanya lapisan tarif dalam penggenaan pajak.

5. Fungsi Demokrasi yaitu wujud sistem gotong royong yang dikaitakan dengan tingkat pelayanan pemerintah kepada masyarakat pembayar pajak.

\section{Jenis-Jenis Pajak}

Dalam hukum berbagai perbedaan pajak terdapat berbagai jenis pajak, menurut Mardiasmo (2011:5) cara membedakannya dapat digolongkan menjadi 3 (tiga) macam, yaitu :

a. Menurut golongan :

1. Pajak langsung 
Adalah pajak yang harus dipikul sendiri oleh wajib pajakdan tidak dapat dibebankan kepada orang lain.

2. Pajak tidak langsung

Adalah pajak yang pada akhirnya dapat dibebankan atau dilimpahkan kepada orang lain.

b. Menurut sifatnya :

1. Pajak subjektif

Adalah pajak yang berpangkal atau berdasarkan pada subjeknya, dalam arti memperhatikan keadaan diri wajib pajak.

2. Pajak objektif

Adalah pajak yang berpangkal pada objeknya tanpa memperhatikan keadaan diri wajib pajak.

c. Menurut lembaga pemungutannya :

1. Pajak pusat

Adalah pajak yang dipungut oleh pemerintah pusat dan digunakan untuk membiayai rumah tangga negara.

2. Pajak daerah

Adalah pajak dipungut oleh pemerintah daerah dan gunakan untuk rumah tangga daerah.

Pajak daerah terdiri atas :

1) Pajak daerah tingkat I (propinsi), contoh : pajak kendaraan bermotor (PKB) dan kendaraan diatas air, pajak bahan bakar kendaraan bermotor.

2) Pajak daerah tingkat II (kota), contoh : pajak hotel dan restoran, pajak reklame, pajak hiburan.

\section{Tarif Pajak}

Tarif pajak didefenisikan sebagai suatu angka tertentu yang digunakan sebagai dasar perhitungan pajak. Ada 4 (empat) macam tarif pajak (Mardiasmo,2011:9), yaitu:

a. Tarif sebanding (proposional)

Yaitu tarif berupa persentase tetap, terhadap berapapun jumlah yang dikenai pajak sehingga besarnya pajak yang terutang proposional terhadap besarnya nilai yang dikenain pajak.

b. Tarif tetap

Yaitu tarif berupa jumlah yang tetap (sama) terhadap berapapun jumlah yang dikenai pajak sehingga besarnya pajak yang terutang tetap.

c. Tarif progresif

Yaitu persentase tarif yang digunakan semakin besar bila jumlah yang dikenai pajak semakin besar. Menurut kenaikan persentase tarifnya, tarif progresif dibagi 3, yaitu :

1. Tarif progresif-progresif

Yaitu kenaikan persentase semakin besar.

2. Tarif progresif tetap

Yaitu kenaikan pesentase tetap.

3. Tarif progresif degresif

Yaitu kenaikan persentase semakin kecil.

d. Tarif degresif

Yaitu persentase tarif yang digunakan semakin kecil bila jumlah yang dikenai pajak semakin besar.

\section{Pajak Kendaraan Bermotor}

Berdasarkan Peraturan Daerah Propinsi Bengkulu Nomor 2 Tahun 2011 tentang pajak kendaraan bermotor, kendaraan bermotor adalah semua kendaraan beroda dua atau lebih beserta gandengannya, yang dioperasikan semua jenis jalan darat dan kendaraan bermotor 
yang dioperasikan di air dengan ukuran isi kotor GT 5 (lima Gross Tonnage) sampai dengan GT 7 (tujuh Gross Tonnage).

Dikecualikan dari pengertian Kendaraan Bermotor adalah :

1. Kereta api.

2. Kendaraan bermotor yang semata-mata digunakan untuk keperluan pertahanan dan keamanan negara.

3. Kendaraan bermotor yang dimiliki dan/atau dikuasai kedutaan, konsulat, perwakilan negara asing dengan asas timbal balik dan lembaga-lembaga internasional yang memperoleh fasilitas pembebasan pajak dari pemerintah.

4. Objek pajak lainnya yang ditetapkan dalam Peraturan Daerah.

Menurut Undang-undang Nomor 18 tahun 1997 tentang pajak daerah bahwa pajak kendaraan bermotor adalah pajak yang dipungut atas kepemilikan atau penguasaan kendaraan bermotor alat berat dan alat berat yang tidak digunakan sebagai alat angkutan orang atau barang di jalan umum.

Selain pengertian pajak kendaraan bermotor ada beberapa istilah teknis penting lainnya yang telah diatur pengertiannya dalam Undang-undang dintaranya :

a. Kendaraan bermotor adalah semua kendaraan beroda dua atau lebih beserta gandengannya yang digunakan di jalan umum, dan digerakkan oleh perangkat teknik berupa motor/peralatan lainnya yang berfungsi untuk mengubah suatu sumber daya energi tertentu menjadi tenaga gerak kendaraan bermotor yang bersangkutan tidak termasuk alat-alat berat dan alat-alat besar.

b. Kendaraan umum adalah setiap kendaraan bermotor yang disediakan untuk dipergunakan oleh umum dengan dipungut bayaran.

c. Mobil penumpang adalah kendaraan bermotor yang dilengkapi sebanyak-banyaknya 8 (delapan) tempat duduk tidak termasuk tempat duduk pengemudi baik dengan maupun tanpa perlengkapan pengangkutan bagasi.

d. Jenis kendaraan bermotor adalah isi ruang yang berbentuk bulat tarak pada mesin kendaraan bermotor yang ikut menentukan besarnya kekuatan mesin.

e. Isi silinder adalah isi ruang yang berbentuk bulat tarak pada mesin kendaraan bermotor yang ikut menentukan besarnya kekuatan mesin.

f. Tenaga kuda (horse power) adalah ukuran daya kemampuan mesin.

g. Tahun pembuatan adalah tahun perakitan.

h. Nilai jual adalah nilai jual kendaraan bermotor yang berlaku.

i. Peningkatan kendaraan bermotor yang selanjutanya peningkatan pajak kendaraan bermotor adalah tanda lunas pajak kendaraan bermotor.

j. Tanda pelunasan dan pengesahan kendaraan bermotor (PPKB) adalah bukti pelunasan pembayaran pajak dan pengesahan kendaraan bermotor.

k. Pemilik adalah hubungan hukum antara orang atau badan dengan kendaraan bermotor yang namanya tercantum dalam Buku Pemilik Kendaraan Bermotor (BPKB).

1. Jalan umum adalah sarana jalan yang dibangun dan pemeliharaannya oleh pemerintah pusat atau daerah yang digunakan untuki lalu lintas kendaraan bermotor.

\section{Kepatuhan Wajib Pajak}

Menurut Gunadi (2005:4), pengertian "kepatuhan pajak (tax compliance) adalah bahwa wajib pajak mempunyai kesediaan untuk memenuhi kewajiban pajaknya sesuai dengan aturanaturan yang berlaku tanpa perlu diadakan pemeriksaan, investigasi seksama, peringatan ataupun ancaman dan penerapan sanksi baik hukuman maupun administrasi".

Kepatuhan pajak diartikan sebagai suatu keadaan yang mana wajib pajak patuh dan mempunyai kesadaran dalam memenuhi kewajiban perpajakan. Menurut Devano dalam bukunya Ni luh (2006:9), mengemukakan kepatuhan dan kesadaran pemenuhan kewajiban perpajakan tercermin dalam situasi sebagai berikut:

1. Wajib pajak memahami dan berusaha untuk memahami semua ketentuan peraturan perundang-undangan perpajakan. 
2. Mengisi formulir pajak dengan lengkap dan jelas.

3. Menghitung jumlah pajak yang terutang dengan benar.

4. Membayar pajak yang terutang tepat pada waktunya.

Kepatuhan wajib pajak sebagai fondasi official assessment dapat dicapai apabila elemenelemen kunci telah diterapkan secara efektif. Menurut Ismawan dalam bukunya Ni Luh (2006:12) elemen-elemen kunci tersebut adalah sebagai berikut:

a. Program pelayanan yang baik kepada wajib pajak.

b. Prosedur yang sederhana dan memudahkan wajib pajak.

c. Program pemantauan kepatuhan dan verifikasi yang efektif.

d. Pemantapan law enforcement secara tegas dan adil.

Ada dua macam kepatuhan, yaitu kepatuhan formal dan kepatuhan material. Kepatuhan formal adalah suatu keadaan dimana pajak memenuhi kewajiban secara formal sesuai dengan ketentuan dalam perundang-undangan perpajakan. Kepatuhan material adalah suatu keadaan dimana wajib pajak memenuihi semua ketentuan material perpajakan, yakni sesuai dengan isi dan jiwa undang-undang perpajakan.

\section{Faktor-Faktor Yang Mempengaruhi Kepatuhan Wajib Pajak}

Ada beberapa faktor-faktor mempengaruhi kepatuhan wajib pajak menurut Aristanti Widyaningsing (2011:6), antara lain:

1. Pemahaman terhadap sistem pemungutan pajak, yaitu :

a. Offical assessment System

Yaitu suatu sistem pemungutan yang memberikan wewenang kepada pemerintah (fiskus) untuk menentukan besarnya pajak yang terutang oleh wajib pajak.

b. Self Assessment System

Yaitu sistem pemungutan pajak yang memberikan wewenang kepada wajib pajak untuk menentukan sendiri besarnya pajak yang terutang.

c. With Holding System

Yaitu pemungutan pajak yang memberikan wewenang kepada pihak ketiga (bukan pemerintah dan bukan wajib pajak) untuk menentukan besarnya wajib pajak yang terutang oleh wajib pajak.

d. Sistem official assessment

Sistem official assessment diterapkan perpajakan Indonesia dalam membayar pajak kendaraan bermotor (PKB). Ciri-ciri sistem official assessment, yaitu :

a. Wewenang untuk menentukan besarnya pajak terutang berada pada fiskus.

b. Wajib pajak bersifat pasif

c. Utang pajak timbul setelah dikeluarkan surat ketetapan pajak oleh fiskus.

2. Kualitas Pelayanan

Menurut Boediono dalam bukunya Ni Luh (2006:34), "pelayanan adalah suatu proses bantuan kepada orang lain dengan cara-cara tertentu yang memerlukan kepekaan dan hubungan inter personal agar tercipta kepuasan dan keberhasilan". Hakikat pelayanan umum adalah sebagai berikut :

a. Meningkatkan mutu dan produktivitas pelaksanaan tugas dan instansi pemerintah di bidang pelayanan umum.

b. Mendorong upaya mengefektifitas sistem dan tata laksana pelayanan sehingga pelayanan umum dapat diselenggarakan secara lebih berdaya guna dan berhasil guna (efektif dan efisien).

c. Mendorong tumbuhnya kreatifitas, prakarsa, damn peran serta masyarakat dalam pembangunan serta meningkatkan kesejahteraan masyarakat lain.

Pelayanan yang berkualitas harus dapat memberikan $4 \mathrm{~K}$, yaitu keamanan, kenyamanan, kelancaran dan kepastian hukum. Kualiatas pelayanan dapat diukur dengan kemampuan memberikan pelayanan yang memuaskan, dapat memberikan pelayanan dengan tanggapan, kemampuan, kesopanan dan sikap dapat dipercaya yang dimiliki oleh 
aparat pajak. Disamping itu juga, kemudahan dalam melakukan hubunngan komunikasi yang baik, memahami kebutuhan wajib pajak, tersedianya fasilitas fisik termasuk sarana komunikasi yang memadai, dan pegawai yang cakap dalam tugasnya.

3. Tingkat pendidikan

Tingkat pendidikan yang semakin tinggi akan menyebabkan masyarakat lebih mudah memahami ketentuan dan peraturan perundang-undangan di bidang perpajakan yang berlaku. Tingkat pendidikan yang semakin rendah juga akan tercermin dalam masih banyaknya wajib pajak yang berpeluang enggan melaksanakan kewajiban perpajakan karena kurangnya pemahaman mereka terhadap sistem perpajakan yang diterapkan.

4. Tingkat Penghasilan

Tingkat penghasilan akan mempengaruhi kepatuhan wajib pajak dalam membayar pajak tepat pada waktunya. Kemampuan wajib pajak dalam memenuhi kewajiban pajak terkait erat dengan besarnya penghasilan,dalam membayar pajak tepat pada waktunya. Kemampuan wajib pajak dalam memenuhi kewajiban pajak terkait erat dengan besarnya penghasilan, maka salah satu hal yang dipertimbangkan dalam pemungutan pajak adalah tingkat penghasilan.

5. Persepsi wajib pajak terhadap sanksi perpajakan.

Sanksi perpajakan diberikan kepada wajib pajak agar wajib pajak mempunyai kesadaran dan patuh terhadap kewajiban pajak. Sanksi perpajakan dalam perundangundangan perpajakan berupa sanksi administrasi (dapat berupa denda dan bunga) dan sanksi pidana. Adanya sanksi perpajakan diharapkan dapat meningkatkan kepatuhan wajib pajak.

\section{Kerangka Analisis}

Faktor-faktor yang mempengaruhi kepatuhan wajib pajak:

1. Pemahaman sistem pemungutan pajak

2. Kualitas pelayanan

3. Tingkat pendidikan

4. Tingkat penghasilan

5. Persepsi sanksi perpajakan

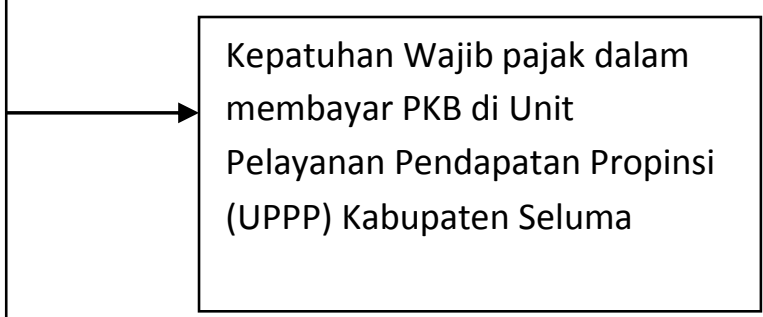

Gambar 1. Kerangka Analisis

\section{HASIL PENELITIAN DAN PEMBAHASAN Karakteristik Responden}

Responden dalam penelitian ini adalah masyarakat atau wajib Pajak Kendaraan Bermotor (PKB) yang memiliki kendaraan roda 2 (dua) di Desa Pasa Tais Kabupaten Seluma. Jumlah responden yang diambil sebanyak 30 orang. Berikut ini disajikan karakteristik responden yang menjadi sampel penelitian ini.

1. Karakteristik responden menurut jenis kelamin

Tabel 1. Karakteristik Responden Berdasarkan Jenis Kelamin

\begin{tabular}{|l|l|c|c|}
\hline No & \multicolumn{1}{|c}{ Tingkat Pendidikan } & $\begin{array}{c}\text { Frekuensi } \\
\text { (Orang) }\end{array}$ & $\begin{array}{c}\text { Persentase } \\
\text { (\%) }\end{array}$ \\
\hline 1 & Perempuan & 4 & 13,33 \\
2 & Laki-laki & 26 & 86,67 \\
\hline & Jumlah & $\mathbf{3 0}$ & $\mathbf{1 0 0}$ \\
\hline
\end{tabular}

Sumber : Data Penelitian 2013 
Berdasarkan Tabel 1 diketahui bahwa mayoritas responden penelitian didominasi oleh responden yang berjenis kelamin laki-laki yakni sebanyak 26 orang atau sebesar 86,67 persen. Sementara responden yang berjenis kelamin perempuan hanya sebesar 13,33 persen. Jumlah responden laki-laki yang lebih besar tersebut disebabkan karena kebetulan di lapangan responden laki-laki lebih banyak ditemui.

2. Karakteristik responden menurut umur

Tabel 2. Karakteristik Responden Berdasarkan Umur

\begin{tabular}{|l|l|c|c|}
\hline No & \multicolumn{1}{|c|}{ Umur } & $\begin{array}{c}\text { Frekuensi } \\
\text { (Orang) }\end{array}$ & $\begin{array}{c}\text { Persentase } \\
\text { (\%) }\end{array}$ \\
\hline 1 & $<20$ Tahun & 5 & 16,67 \\
2 & $21-30$ Tahun & 13 & 43,33 \\
3 & 31 - 40 Tahun & 10 & 33,33 \\
4 & $>40$ Tahun & 2 & 6,67 \\
\hline
\end{tabular}

Sumber : Data Penelitian 2013

Berdasarkan Tabel 2 di atas diketahui bahwa mayoritas responden penelitian didominasi oleh responden yang berusia antara 21 - 30 tahun yakni sebanyak 13 orang atau sebesar 43,33 persen. Urutan kedua ditempati oleh responden dengan usia antara $31-40$ tahun sebesar 10 orang atau sebanyak 33,33 persen. Sementara sisanya adalah responden yang berusia kurang dari 20 tahun dan telah berusia di atas 40 tahun. Kondisi ini berarti bahwa wajib pajak yang membayar pajak Kendaraan Bermotor (PKB) di kalangan responden dengan berbagai kalangan usia, baik muda maupun dewasa.

3. Karakteristik responden menurut pendidikan

Tabel 3. Karakteristik Responden Berdasarkan Tingkat Pendidikan

\begin{tabular}{|c|c|c|c|}
\hline No & Tingkat Pendidikan & $\begin{array}{c}\text { Frekuensi } \\
\text { (Orang) }\end{array}$ & $\begin{array}{c}\text { Persentase } \\
(\%)\end{array}$ \\
\hline 1 & Sekolah Dasar (SD) & 2 & 6,67 \\
\hline 2 & Sekolah Menengah Pertama (SMP) & 13 & 43,33 \\
\hline 3 & Sekolah Menengah Umum (SMU) & 12 & 40,00 \\
\hline 4 & Diploma & 1 & 3,33 \\
\hline 5 & Sarjana (S1) & 2 & 6,67 \\
\hline & Jumlah & 30 & 100 \\
\hline
\end{tabular}

Sumber : Data Penelitian 2013

Berdasarkan Tabel 3 di atas diketahui bahwa mayoritas responden penelitian didominasi oleh responden yang memiliki pendidikan sekolah menengah pertama yakni sebanyak 13 orang atau sebesar 43,33 persen. Urutan kedua ditempati oleh responden dengan pendidikan sekolah menengah umum (SMU) sebanyak 12 orang atau sebanyak 40 persen. Sementara sisanya adalah responden yang memiliki tingkat pendidikan sekolah dasar, diploma, dan sarjana.

\section{Persepsi Responden Terhadap Indikator Penelitian}

a. Persepsi responden terhadap pemahaman sistem pemungutan pajak.

Berikut ini disajikan persepsi responden terhadap item-item yang ditanyakan tersebut. 
Tabel 4. Persepsi Responden terhadap pemahaman sistem pemungutan pajak

\begin{tabular}{|c|l|c|c|c|c|c|c|}
\hline No Indikator & \multicolumn{7}{c|}{ Jawaban } \\
\hline 1 & $\begin{array}{l}\text { Apakah dalam membayar Pajak Kendaraan } \\
\text { Bermotor (PKB), Wajib pajak memperoleh } \\
\text { Ketepatan informasi dalam perhitungan PKB-nya? }\end{array}$ & 0 & 24 & 2 & 4 & 0 & 110 \\
\hline 2 & $\begin{array}{l}\text { Apakah Wajib Pajak mengerti sistem pemungutan } \\
\text { PKB menggunakan Official Assessment System? }\end{array}$ & 0 & 22 & 4 & 4 & 0 & 108 \\
\hline 3 & $\begin{array}{l}\text { Kesadaran Wajib Pajak bahwa melakukan } \\
\text { kepatuhan membayar PKB adalah suatu } \\
\text { kewajiban? }\end{array}$ & 0 & 20 & 10 & 0 & 0 & 110 \\
\hline & & & & & & \\
\hline
\end{tabular}

Sumber: Data Penelitian, 2013

Keterangan:

$90-162=$ Sangat Tidak Setuju (STS)

$163-234=$ Tidak Setuju (TS)

$235-306=\operatorname{Netral}(\mathrm{N})$

$307-378=$ Setuju (S)

$379-450=$ Sangat Setuju (SS)

Berdasarkan Tabel 4 jumlah total skor 328 menunjukkan persepsi 30 orang responden secara rata-rata menyatakan setuju bahwa faktor-faktor yang mempengaruhi kepatuhan wajib pajak dalam membayar pajak kendaraaan bermotor di Unit Pelayanan Pendapatan Propinsi (UPPP) Kabupaten Seluma adalah pemahaman sistem pemungutan pajaknya.

Dari tabel 4 selanjutnya Secara kriterium faktor pemahaman sistem pemungutan pajak dapat digambarkan pada gambar 4. Sebagai berikut:

\section{Gambar 4. Interval Jawaban Responden Terhadap pemahaman sistem pemungutan pajak}

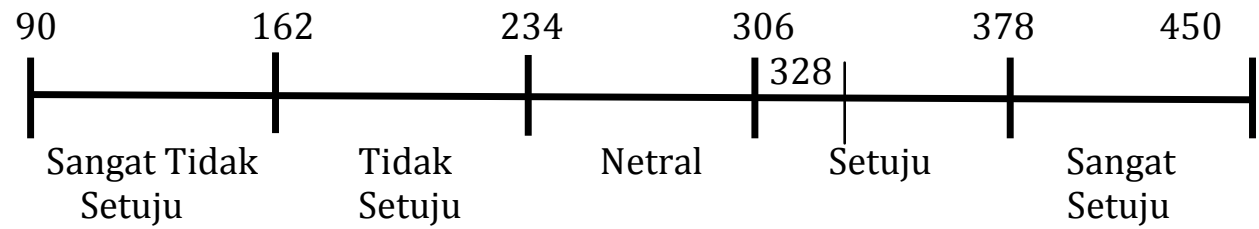

Sumber: Data Penelitian, 2013

Pada gambar 4. di atas menunjukkan posisi nilai persepsi responden terhadap factor pemahaman sistem pemungutan pajak mempengaruhi kepatuhan wajib pajak dalam membayar pajak kendaraan bermotor di Unit Pelayanan Pendapatan Propinsi (UPPP) Kabupaten Seluma dengan total skor 328 berada pada interval 308-381, kriteria setuju.

b. Pesepsi responden terhadap kualitas pelayanan

Berikut ini disajikan persepsi responden terhadap item-item yang ditanyakan tersebut

Tabel 5. Persepsi Responden terhadap Kualitas pelayanan

\begin{tabular}{|c|c|c|c|c|c|c|c|}
\hline \multirow{2}{*}{ No } & \multirow{2}{*}{ Indikator } & \multicolumn{5}{|c|}{ Jawaban } & \multirow{2}{*}{ Jumlah } \\
\hline & & SS & $\mathbf{S}$ & $\mathbf{N}$ & TS & STS & \\
\hline 1 & Fasilitas yang anda terima sudah memadai? & 0 & 17 & 10 & 3 & 0 & 104 \\
\hline 2 & $\begin{array}{l}\text { Menurut anda, apakah petugas pajak telah } \\
\text { menguasai teknologi yang digunakan? }\end{array}$ & 0 & 16 & 14 & 0 & 0 & 106 \\
\hline 3 & $\begin{array}{l}\text { Menurut anda, apakah dengan memberikan } \\
\text { senyum dan ramah kepada Wajib Pajak dapat } \\
\text { menenangkan suasana yang kurang kondusif? }\end{array}$ & 0 & 22 & 8 & 0 & 0 & 112 \\
\hline
\end{tabular}

Sumber: Data penelitian, 2013 
Keterangan:

$90-162=$ Sangat Tidak Setuju (STS)

$163-234=$ Tidak Setuju (TS)

$235-306=\operatorname{Netral}(\mathrm{N})$

$307-378=$ Setuju $(\mathrm{S})$

$379-450=$ Sangat Setuju (SS)

Berdasarkan Tabel 5 jumlah total skor 322 menunjukkan pesepsi 30 orang responden secara rata-rata menyatakan setuju bahwa faktor-faktor yang mempengaruhi kepatuhan wajib pajak dalam membayar pajak kendaraaan bermotor di Unit Pelayanan Pendapatan Propinsi (UPPP) Kabupaten Seluma adalah kualitas pelayanan.

Dari tabel 5 selanjutnya Secara kriterium faktor kualitas pelayanan dapat digambarkan pada gambar 5. Sebagai berikut:

\section{Gambar 5. Interval Jawaban Responden Terhadap Kualitas Pelayanan}

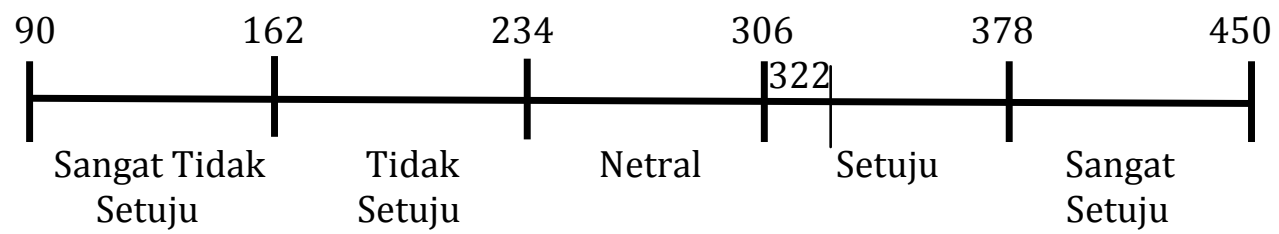

Sumber: Data Penelitian, 2013

Pada gambar 5. di atas menunjukkan posisi nilai persepsi responden terhadap faktor kualitas pelayanan mempengaruhi keputusan wajib pajak dalam membayar pajak kendaraan bermotor di Unit Pelayanan Pendapatan Propinsi (UPPP) Kabupaten Seluma dengan total skor 322 berada pada interval 308-381, kriteria setuju.

c. Persepsi responden terhadap tingkat pendidikan. tersebut.

Berikut ini disajikan persepsi responden terhadap item-item yang ditanyakan

Tabel 6. Persepsi Responden terhadap tingkat pendidikan

\begin{tabular}{|l|l|c|c|c|c|c|c|}
\hline No Indikator & \multicolumn{7}{|c|}{ Jawaban } \\
\hline 1 & $\begin{array}{l}\text { Latar belakang pendidikan yang dimiliki Wajib } \\
\text { Pajak mempengaruhi kepatuhan dalam } \\
\text { membayar PKB? }\end{array}$ & 0 & 19 & 6 & 5 & 0 & 104 \\
\hline 2 & $\begin{array}{l}\text { Apakah anda memiliki keahlian dalam bidang } \\
\text { perpajakan? }\end{array}$ & 0 & 23 & 3 & 3 & 1 & 108 \\
\hline 3 & $\begin{array}{l}\text { Apakah anda mengerti dalam pengisian } \\
\text { formulir? }\end{array}$ & 0 & 10 & 18 & 2 & 0 & 98 \\
\hline \multicolumn{1}{|c|}{ Total Skor }
\end{tabular}

Sumber: Data Penelitian, 2013

Keterangan:

$90-162=$ Sangat Tidak Setuju (STS)

$163-234=$ Tidak Setuju (TS)

$235-306=\operatorname{Netral}(\mathrm{N})$

$307-378=$ Setuju $(\mathrm{S})$

$379-450=$ Sangat Setuju (SS)

Berdasarkan Tabel 6 jumlah total skor 310 menunjukkan pesepsi 30 orang responden secara rata-rata menyatakan setuju bahwa faktor-faktor yang mempengaruhi kepatuhan wajib pajak dalam membayar pajak kendaraaan bermotor di Unit Pelayanan Pendapatan Propinsi (UPPP) Kabupaten Seluma adalah tingkat pendidikan. 
Dari tabel 6 selanjutnya Secara kriterium faktor tingkat pendidikan dapat digambarkan pada gambar 6 . Sebagai berikut:

Gambar 6. Interval Jawaban Responden Terhadap tingkat pendidikan

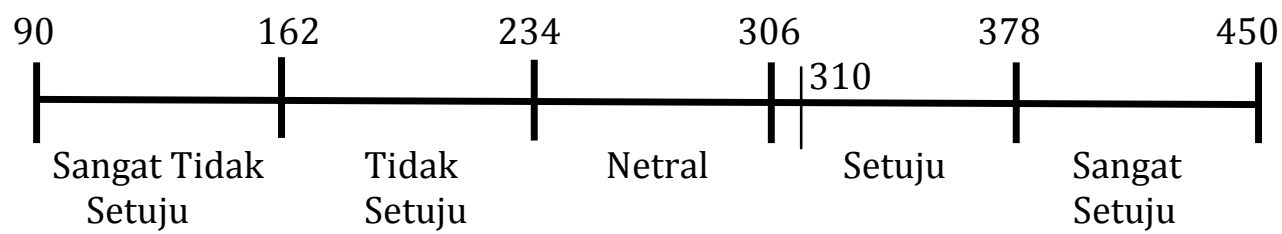

Sumber: Data Penelitian, 2013

Pada gambar 6 di atas menunjukkan posisi nilai persepsi responden terhadap faktor tingkat pendidikan mempengaruhi keputusan wajib pajak dalam membayar pajak kendaraan bermotor di Unit Pelayanan Pendapatan Propinsi (UPPP) Kabupaten Seluma dengan total skor 310 berada pada interval 308-381, kriteria setuju.

d. Persepsi responden terhadap tingkat penghasilan

Berikut ini disajikan persepsi responden terhadap item-item yang ditanyakan tersebut.

Tabel 7. Persepsi Responden terhadap tingkat penghasilan

\begin{tabular}{|c|c|c|c|c|c|c|c|}
\hline \multirow{2}{*}{ No } & \multirow{2}{*}{ Indikator } & \multicolumn{5}{|c|}{ Jawaban } & \multirow{2}{*}{ Jumlah } \\
\hline & & SS & $S$ & $\mathbf{N}$ & TS & STS & \\
\hline 1 & $\begin{array}{l}\text { Apakah Wajib Pajak menyanggupi nilai PKB yang } \\
\text { dikenakan? }\end{array}$ & 0 & 16 & 7 & 7 & 0 & 99 \\
\hline 2 & $\begin{array}{l}\text { Kemampuan Wajib Pajak dalam memenuhi PKB } \\
\text { terkait erat dengan besarnya penghasilan? }\end{array}$ & 2 & 22 & 6 & 0 & 0 & 106 \\
\hline 3 & $\begin{array}{l}\text { Besarnya pajak yang dikenakan sesuai dengan } \\
\text { tingkat penghasilan yang dimiliki Wajib Pajak? }\end{array}$ & 0 & 16 & 8 & 6 & 0 & 100 \\
\hline & Total Skor & & & & & & 305 \\
\hline
\end{tabular}

Sumber: data penelitian,2013

Keterangan:

$90-162=$ Sangat Tidak Setuju (STS)

$163-234=$ Tidak Setuju (TS)

$235-306=$ Netral $(\mathrm{N})$

$307-378=$ Setuju $(\mathrm{S})$

$379-450=$ Sangat Setuju (SS)

Berdasarkan Tabel 7 jumlah total skor 305 menunjukkan pesepsi 30 orang responden secara rata-rata menyatakan netral bahwa faktor-faktor yang mempengaruhi kepatuhan wajib pajak dalam membayar pajak kendaraaan bermotor di Unit Pelayanan Pendapatan Propinsi (UPPP) Kabupaten Seluma adalah tingkat penghasilan.

Dari tabel 7 selanjutnya Secara kriterium faktor tingkat penghasilan dapat digambarkan pada gambar 7. Sebagai berikut:

\section{Gambar 7. Interval Jawaban Responden Terhadap tingkat penghasilan}

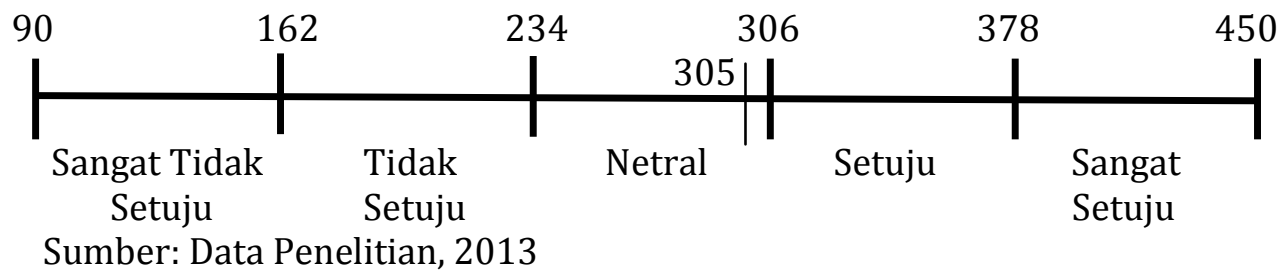

Pada gambar 7 di atas menunjukkan posisi nilai persepsi responden terhadap faktor tingkat penghasilan mempengaruhi keputusan wajib pajak dalam membayar pajak 
kendaraan bermotor di Unit Pelayanan Pendapatan Propinsi (UPPP) Kabupaten Seluma dengan total skor 305 berada pada interval 235-306, kriteria netral.

e. Persepsi responden persepsi wajib pajak terhadap sanksi perpajakan

Berikut ini disajikan persepsi responden terhadap item-item yang ditanyakan tersebut.

Tabel 8. Persepsi Responden persepsi wajib pajak terhadap sanksi perpajakan

\begin{tabular}{|l|l|l|c|c|c|c|c|}
\hline \multicolumn{1}{|c|}{ Indikator } & \multicolumn{1}{c|}{ Jawaban } & ST & S & N & TS & STS & Jumlah \\
\hline 1 & $\begin{array}{l}\text { Apakah Wajib Pajak mengerti adanya sanksi yang } \\
\text { dikenakan bila Wajib Pajak terlambat dalam } \\
\text { pembayaran PKB? }\end{array}$ & 0 & 25 & 3 & 2 & 0 & 113 \\
\hline 2 & $\begin{array}{l}\text { Apakah besarnya sanksi yang dikenakan telah } \\
\text { sesuai? }\end{array}$ & 0 & 21 & 7 & 2 & 0 & 109 \\
\hline 3 & $\begin{array}{l}\text { Apakah petugas pajak menjelaskan rincian } \\
\text { tentang sanksi yang dikenakan oleh Wajib Pajak, } \\
\text { bila terjadi keterlamabatan dalam pembayaran } \\
\text { PKB? }\end{array}$ & 0 & 12 & 9 & 9 & 0 & 93 \\
\hline Total skor & & & & & & $\mathbf{3 1 5}$ \\
\hline
\end{tabular}

Sumber: Data Penelitian, 2013

Keterangan:

$90-162=$ Sangat Tidak Setuju (STS)

$163-234=$ Tidak Setuju (TS)

$235-306=\operatorname{Netral}(\mathrm{N})$

$307-378=$ Setuju (S)

$379-450=$ Sangat Setuju (SS)

Berdasarkan Tabel 8 jumlah total skor 315 menunjukkan pesepsi 30 orang responden secara rata-rata menyatakan setuju bahwa faktor-faktor yang mempengaruhi kepatuhan wajib pajak dalam membayar pajak kendaraaan bermotor di Unit Pelayanan Pendapatan Propinsi (UPPP) Kabupaten Seluma adalah persepsi wajib pajak terhadap sanksi perpajakan.

Dari tabel 8 selanjutnya Secara kriterium faktor persepsi wajib pajak terhadap sanksi perpajakan dapat digambarkan pada gambar 8 . Sebagai berikut:

\section{Gambar 8. Interval Jawaban Responden persepsi wajib pajak terhadap sanksi perpajakan}

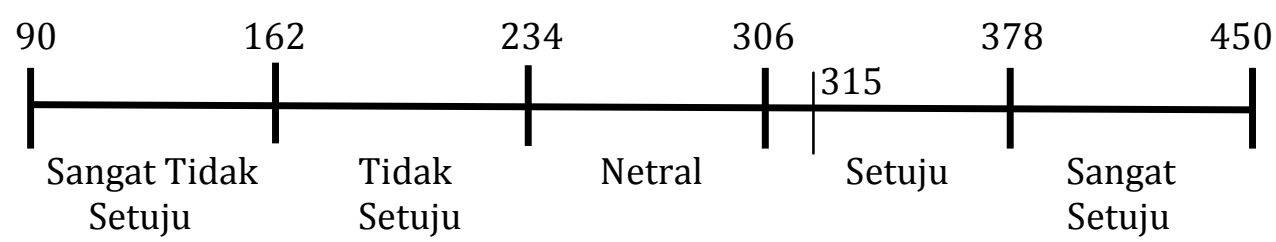

Sumber: Data Penelitian, 2013

Pada gambar 8 di atas menunjukkan posisi nilai persepsi responden terhadap faktor persepsi wajib pajak terhadap sanksi perpajakan mempengaruhi keputusan wajib pajak dalam membayar pajak kendaraan bermotor di Unit Pelayanan Pendapatan Propinsi (UPPP) Kabupaten Seluma dengan total skor 315 berada pada interval 308-381, kriteria setuju.

\section{Pembahasan}

Hasil kuisioner diperoleh persepsi responden tentang faktor-faktor yang mempengaruhi kepatuhan wajib pajak dalam membayar Pajak Kendaraan Bermotor (PKB) di Unit Pelayanan Pendapatan Propinsi (UPPP) Kabupaten Seluma dengan indikator penelitian terdiri dari system pemungutan pajak, kualitas pelayanan, tingkat pendidikan, tingkat penghasilan, dan persepsi wajib pajak terhadap sanksi administrasi. 
Secara rata-rata persepsi responden terhadap 5 (lima) faktor yang mempengaruhi kepatuhan wajib pajak dalam membayar Pajak Kendaraan Bermotor (PKB) di UPPP Kabupaten Seluma adalah setuju bahwa 5 (lima) faktor tersebut mempengaruhi kepatuhan wajib pajak dalam membayar Pajak Kendaraan Bermotor di UPPP Kabupaten Seluma dengan total skor jawaban berada pada interval 308-381 dengan kriteria setuju.

Secara rinci persepsi responden terhadap 5 (lima) faktor-faktor yang mempengaruhi kepatuhan wajib pajak dalam membayar Pajak Kendaraan Bermotor (PKB) di UPPP Kabupaten Seluma dapat dilihat pada tabel 9.

Tabel 9. Total Skor Persepsi Respoden

\begin{tabular}{|c|l|c|c|}
\hline \multicolumn{1}{|c|}{ No } & Indikator Kepatuhan Wajib Pajak & Total Skor & Kriteria \\
\hline 1 & Pemahaman terhadap sistem pemungutan pajak & $\mathbf{3 2 8}$ & Setuju \\
\hline 2 & Kualitas Pelayanan & $\mathbf{3 2 2}$ & Setuju \\
\hline 3 & Tingkat pendidikan & $\mathbf{3 1 0}$ & Setuju \\
\hline 4 & Tingkat penghasilan & $\mathbf{3 0 5}$ & Netral \\
\hline 5 & Persepsi wajib pajak terhadap sanksi perpajakan & $\mathbf{3 1 5}$ & Setuju \\
\hline \multicolumn{2}{r|}{ Total Skor } & $\mathbf{3 1 6}$ & Setuju \\
\hline
\end{tabular}

Sumber data Penelitian, 2013

Keterangan:

$90-162=$ Sangat Tidak Setuju (STS)

$163-234=$ Tidak Setuju (TS)

$235-306=\operatorname{Netral}(\mathrm{N})$

$308-378=$ Setuju (S)

$379-450=$ Sangat Setuju (SS)

Hasil penelitian pada tabel 9 di atas menunjukkan bahwa secara rata-rata kepatuhan wajib pajak dalam membayar Pajak Kendaraan Bermotor (PKB) di UPPP Kabupaten Seluma dengan kriteria setuju dengan skor 316 Urutan nilai tertinggi sampai terrendah meliputi : pemahaman terhadap sistem pemungutan pajak (328), kualitas pelayanan (322), persepsi wajib pajak terhadap sanksi perpajakan (315), tingkat pendidikan (310), dan tingkat penghasilan (305). Nilai ini menunjukkan faktor di atas menurut wajib pajak di desa Pasar Tais Kabupaten Seluma akan mempengaruhi kepatuhan wajib pajak dalam membayar Pajak Kendaraan Bermotor (PKB) di UPPP Kabupaten Seluma.

Secara kriterium faktor-faktor yang mempengaruhi kepatuhan wajib pajak dalam membayar Pajak Kendaraan Bermotor (PKB) di UPPP Kabupaten Seluma dapat digambarkan pada gambar 9 . Sebagai berikut:

\section{Gambar 9. Interval Jawaban Responden Terhadap kepatuhan wajib pajak dalam membayar Pajak Kendaraan Bermotor (PKB) di UPPP Kabupaten Seluma}

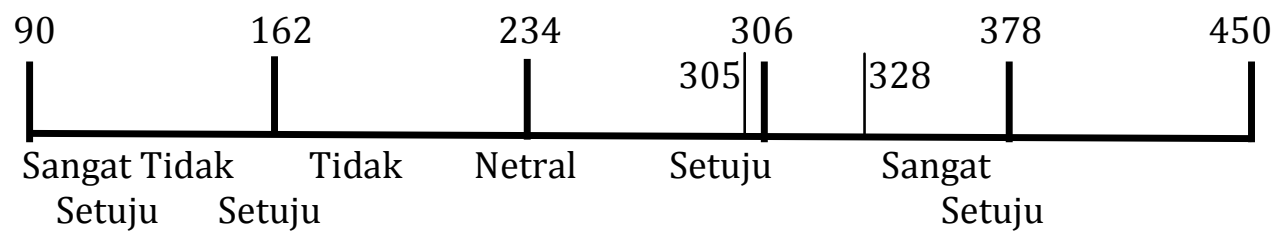

Sumber: Data Penelitian, 2013

Pada gambar 9 di atas menunjukkan posisi nilai terendah persepsi responden terhadap kepatuhan wajib pajak dalam membayar pajak kendaraan bermotor di Unit Pelayanan Pendapatan Propinsi (UPPP) Kabupaten Seluma dengan nilai 305 berada pada interval 234-306, kriteria netral dan tertinggi persepsi responden terhadap produk dengan nilai 328, berada pada interval 308-381, kriteria setuju

Untuk lebih jelas akan dibahas satu persatu tentang faktor-faktor yang mempengaruhi kepatuhan wajib pajak dalam membayar Pajak Kendaraan Bermotor: 
a. Pemahaman terhadap sistem pemungutan pajak

Kondisi ini berarti bahwa pemahaman terhadap sistem pemungutan pajak merupakan faktor penting yang menjadi pertimbangan wajib pajak dalam mempengaruhi kepatuhan dalam membayar Pajak Kendaraan Bermotor (PKB). Hal ini juga berarti bahwa jika persepsi/keyakinan wajib pajak terhadap pemahaman sistem pemungutan pajak di Indonesia yaitu Official Assesment System sudah sesuai dengan ketentuan yang berlaku sehingga wajib pajak dapat memenuhi kewajibannya dalam membayar Pajak Kendaraan Bermotornya.

Sistem official assessment system diterapkan perpajakan Indonesia dalam membayar pajak kendaraan bermotor (PKB). Adapun ciri-ciri sistem official assessment system, meliputi:

1. Wewenang untuk menentukan besarnya pajak terutang berada pada pemerintah (fiskus).

2. Wajib pajak bersifat pasif

3. Utang pajak timbul setelah dikeluarkan surat ketetapan pajak oleh pemerintah (fiskus), yaitu melalui Unit Pelayanan Propinsi (UPPP) Kabupaten Seluma perpanjangtanganan dari kantor Dinas Pendapatan Propinsi Bengkulu.

b. Kualitas Pelayanan

Faktor kualitas pelayanan memiliki pengaruh yang juga besar terhadap kepatuhan wajib pajak dalam membayar Pajak Kendaraan Bermotor (PKB). Kondisi ini berarti bahwa jika persepsi/keyakinan konsumen terhadap kualitas pelayanan semakin meningkat akan menjadi pertimbangan wajib pajak dalam membayar Pajak Kendaraan Bermotor (PKB) tepat waktu.

Kualitas pelayanan dapat dinilai melalui sebagai berikut:

1. Dapat meningkatkan mutu dan produktivitas pelaksanaan tugas dan instansi pemerintah di bidang pelayanan.

2. Mendorong upaya mengefektifitas sistem dan tata laksana pelayanan sehingga kualitas pelayanan dapat diselenggarakan secara lebih berdaya guna dan berhasil guna (efektif dan efisien).

3. Mendorong tumbuhnya kreatifitas, prakarsa, dimana peran serta wajib pajak dalam pembangunan serta meningkatkan kesejahteraan masyarakat lain.

Kualitas pelayanan dapat diartikan adanya kemampuan memberikan pelayanan yang memuaskan, memberikan pelayanan dengan tanggapan, kemampuan, kesopanan, dan sikap dapat dipercaya yang dimiliki oleh aparat instansi pajak yaitu pegawai Unit Pelayanan Pendapatan Propinsi (UPPP) Kabupaten Seluma.

c. Tingkat Pendidikan

Faktor tingkat pendidikan memiliki pengaruh yang juga besar terhadap kepatuhan wajib pajak dalam membayar Pajak Kendaraan Bermotor (PKB). Kondisi ini berarti bahwa jika persepsi/keyakinan wajib pajak terhadap tingkat pendidikan semakin tinggi akan menjadi pertimbangan wajib pajak mengerti prosedur dalam membayar Pajak Kendaraan Bermotor (PKB).

Tingkat pendidikan wajib pajak yang semakin tinggi dapat memudahkan wajib pajak memahami prosedut dan ketentuan dalam membayar Pajak Kendaraan Bermotor (PKB).tingkat pendidikan yang rendah berpeluang tidak mengerti dan tidak memahami adanya ketentuan dan prosedur dalam membayar Pajak kendaraan bermotor (PKB) atau adanya sanksi bila terjadi keterlambatan dalam membayar Pajak Kendaraan Bermotor (PKB).

d. Tingkat Penghasilan

Faktor tingkat penghasilan memiliki pengaruh yang juga besar terhadap kepatuhan wajib pajak dalam membayar Pajak Kendaraan Bermotor (PKB). Kondisi ini berarti bahwa jika persepsi/keyakinan wajib pajak terhadap tingkat penghasilan semakin tinggi akan menjadi pertimbangan wajib pajak dapat memenuhi kewajibannya dalam membayar Pajak Kendaraan Bermotor (PKB). 
Kemampuan wajib pajak dalam membayar Pajak Kendaraan Bermotor (PKB) terkait erat dengan besarnya penghasilan wajib pajak sehingga wajib pajak dapat memenuhi kewajibannya membayar Pajak Kendaraan Bermotornya tepat waktu.

e. Persepsi wajib pajak terhadap sanksi perpajakan

Faktor persepsi wajib pajak terhadap sanksi perpajakan memiliki pengaruh yang juga besar terhadap kepatuhan wajib pajak dalam membayar Pajak Kendaraan Bermotor (PKB). Kondisi ini berarti bahwa jika persepsi/keyakinan wajib pajak terhadap sanksi perpajakan semakin tinggi akan menjadi pertimbangan wajib pajak dapat memenuhi kewajibannya dalam membayar Pajak Kendaraan Bermotor (PKB).

Sanksi perpajakan diberikan kepada wajib pajak mempunyai kesadaran dan patuh terhadap kewajibannya dalam membayar Pajak Kendaraan Bermotor (PKB). Sanksi perpajakan yang berlaku di Unit Pelayanan Pendapatan Propinsi (UPPP) Kabupaten Seluma yaitu sanksi administrasi berupa denda terhitung dari pajak yang dikenakan pada kendaraan yang dimiliki wajib pajak lewat dari jatuh tempo tertera di Surat Tanda Nomor Kendaraan Bermotor (STNK). Adanya dikenakan sanksi perpajakan diharapkan dapat meningkatkan kepatuhan wajib pajak dalam membayar Pajak Kendaraan Bermotor (PKB).

\section{Kesimpulan}

Setelah melakukan analisis terhadap 5 (lima) faktor yang mempengaruhi wajib pajak dalam membayar Pajak Kendaraan Bermotor (PKB) di bulan Juli tahun 2013 di Unit Pelayanan Pendapatan Propinsi (UPPP) Kabupaten Seluma, maka ditarik kesimpulan secara rata-rata persepsi responden terhadap 5 (lima) faktor yang mempengaruhi tingkat kepatuhan wajib pajak dalam membayar Pajak Kendaraan Bermotor (PKB) di UPPP Kabupaten Seluma menunjukkan setuju, ini terlihat dengan skor rata-rata jawaban responden 316 berada pada interval 308-381 dalam kriteria setuju. Ke 5 (lima) faktor yang mempengaruhi tingkat kepatuhan wajib pajak dalam membayar Pajak Kendaraan Bermotor (PKB) di UPPP Kabupaten Seluma menurut urutan nilai tertinggi sampai nilai terendah, yaitu :

1. Pemahaman terhadap sistem pemungutan pajak (328).

2. Kualitas pelayanan (322).

3. Tingkat pendidikan (315).

4. Persepsi wajib pajak terhadap sanksi perpajakan (315).

5. Tingkat penghasilan (305).

\section{Saran}

Berdasarkan hasil kesimpulan yang telah diuraikan, maka dapat disarankan hal-hal sebagai berikut :

1. Bagi Unit Pelayanan Pendapatan Propinsi (UPPP) Kabupaten Seluma hendaknya agar mempertahankan tingkat kepatuhan wajib Pajak Kendaraan Bermotornya yang sudah ada, dan meningkatkan pengawasannya kepada wajib pajak kendaraan bermotor yang belum patuh dengan cara melaksanakan operasi Surat Tanda Nomor Kendaraan Bermotor (STNK) dijalan, dengan operasi tersebut wajib pajak kendaraan bermotor akan merasa terawasi dan dapat membayar pajak tepat pada jatuh tempo dan bukan membayar pajak setelah tanggal jatuh tempo.

2. Bagi wajib pajak kendaraan bermotor agar selalu taat pada peraturan yang berlaku, salah satunya seperti membayar pajak kendaraan bermotor tepat pada waktunya atau tepat pada tanggal jatuh tempo.

\section{DAFTAR PUSTAKA}

Agung Ayu Fatty Ryan. 2008. Pengaruh Pengenaan Sanksi Administrasi Pajak Kendaraan Bermotor Terhadap Tingkat Kepatuhan Wajib Pajak Kendaraan Bermotor Pada 
Samsat Kab Tangerang. Skripsi tidak diterbitkan. Jakarta Program Sarjana Ekonomi Akuntansi UPN “Veteran” Jakarta.

Dinas Pendapatan Daerah Provinsi Bengkulu. 2013. Daftar Urut Kepangkatan (DUK) \& Struktur Organisasi UPPP Kabupaten Seluma.

Fatma Yulianti. 2007. Analisis Pengaruh Kepatuhan Wajib Pajak Terhadap Sanksi Administrasi Perpajakan Dalam Memenuhi Kewajiban PPH Badan Pasal 25 Pada KPP Jakarta Cilandak. Skripsi tidak diterbitkan. Jakarta Program Sarjana Ekonomi Akuntansi UPN “Veteran” Jakarta.

Gunadi. 2005. Fungsi Pemeriksaan Terhadap Peningkatan Kepatuhan pajak (Tax Complience). Jurnal Perpajakan Indonesia Vol 4 No.5: 4-9

Ni Luh Supadmi. 2006. Meningkatkan Kepatuhan Wajib Pajak Melalui Kualitas Pelayanan. http: // ejournal.unud.ac.id / abstrak / ok\%20supadmi.pdf. Diunduh 7 Mei 2013.

Muhtadim. 2007. Analisis Pengaruh Penerimaan Sanksi Administrasi Pajak Kendaraan Bermotor (PKB) Pada Samsat Jakarta Selatan. Skripsi tidak diterbitkan. Jakarta Program Sarjana Ekonomi Akuntansi UPN “Veteran” Jakarta.

Mardiasmo. 2011. Perpajakan. Andi Publisher. Yogyakarta.

Republik Indonesia. Undang-undang Nomor 18 Tahun 1997 tentang Pajak Daerah dan Retribusi Daerah.

Republik Indonesia. Undang-undang Nomor 28 Tahun 2007 tentang Ketentuan Umum dan Tata Cara Perpajakan.

Republik Indonesia. Undang-undang Nomor 28 Tahun 2008 tentang Pajak Daerah.

Republik Indonesia. Peraturan Pemerintah Propinsi Bengkulu Nomor 2 Tahun 2011 tentang Pajak Daerah Propinsi Bengkulu.

Sugiono. 2012. Metode Penelitian Bisnis. CV. Alfabeta. Bandung

Sri Rustiyaningsih. 2011. Faktor-Faktor Mempengaruhi Kepatuhan Wajib Pajak. Skripsi tidak diterbitkan. Madiun Program Sarjanan Ekonomi Akuntansi Universitas Katolik Widya Mandala Madiun.

Widyaningsih, Aristanti. 2011. Hukum Pajak dan Perpajakan. Alfabeta. Bandung. 